\author{
Janina Filek \\ Cracow University of Economics \\ Faculty of Public Economy and Administration \\ Department of Philosophy \\ e-mail: filekj@uek.krakow.pl
}

\title{
Social economy as a new challenge*
}

\begin{abstract}
The article discusses the concept of the social economy. In the first part, some essential historical sources of the subject matter are described. The second part deals with the concept of social economy, taking into special consideration its definitional problems, founding values and characteristic principles as well as the dilemmas and difficulties connected with its implementation.
\end{abstract}

Keywords: social economy, catholic social teaching

JEL Classification: A13, B55, L31

If the realm of making has invaded the space of essential action, then morality must invade the realm of making, from which it has formerly stayed aloof, and must do so in the form of public policy.

Hans Jonas, "The Imperative of Responsibility"

\footnotetext{
* The article is an updated version of the paper published in Polish in the Annales. Ethics in Economic Life, 12(1), 179-188.
} 


\title{
1. Instead of an introduction-a few beginnings
}

\subsection{The first beginning, or the beginning of beginnings}

In an attempt to grasp the concept of the social economy, let us begin our journey with one of the oldest sources of religious and social thought - the Old Testament.

\begin{abstract}
You are to sow your land and gather its crops for six years, but you are to let it rest the seventh year, leaving it unplanted. The poor of your people may eat from it [...]. You are to do the same with your vineyards and olive groves. (Ex 23: 1011)

If your relative becomes so poor that he is indebted to you, then you are to support him. You are to let him live with you just like the resident alien and the traveler. You are not to take interest or profit from him. (Lev 25: 35-36)

You must cancel your debts at the end of every seventh year [...]. [...] Every creditor must cancel the loan that his friend borrowed, and he must not pressure his friend or brother to repay it [...]. You may exact payment from a foreigner, but cancel whatever your brother owes you. Moreover, there will be no poor person among you... (Deut 15: 1-4) ${ }^{1}$
\end{abstract}

As Peter Berger points out, in contemporary Catholic thought, this central theme of Christian ethics has been conveyed in the formula of "the preferential option for the poor", which means that the assistance given to the poor is a religious obligation, and that the situation of the poor in a given society is one of the basic criteria for the moral evaluation of that society (cf. Berger, 1994, p. 7).

\subsection{The second beginning, or the beginning of the discussion}

Let us pause our journey towards the idea of social economy and look at the beginning of the modern discussion concerning the best social model. Generally speaking, the origins of this debate go back to the publication of Thomas Hobbes' works ${ }^{2}$; yet, other great philosophers contributed to the discussion as well. They were split into two camps: a position granting all humans the right to freedom (John Locke, Adam Smith, Bernard de Mandeville), and thus the conviction that the free market system (Smith) is the best self-regulatory mechanism, and the stance grounded in the belief that interventionism and top-down control of human actions are necessary (Hobbes, and later also statists of different types). Proponents of both positions, praising the advantages of the sociopolitical model

\footnotetext{
${ }^{1}$ To avoid misunderstandings, it should be noted that in the Pentateuch, a friend or a brother [Polish version: bliźni] is every person who becomes closer "to us." Thus, the literal understanding of a brother" as one connected with blood ties should be ruled out.

${ }^{2}$ Elementa philosophiae was published between 1642 and 1658, while Leviathan was published in 1651 .
} 
proposed by themselves, provide a remarkable insight into the negative effects of implementing the model of their opponents. Nonetheless, they hardly ever-if ever - realize the negative consequences of applying the principles of the model that they support. The advocates of liberalism do not notice that their version of the economy becomes "a sphere that is autonomous in relation to society, and which operates paying no heed to social problems and demands" (Skąpska, 2007, p. 30). On the other hand, the supporters of interventionism, i.e., the concept according to which the state should take over a significant part of duties (including economic affairs and security, but also welfare responsibilities), do not recognize the dangers that arise from restricting the rights of an individual and decreasing the efficiency of business activity, which follow from their model, or the threat of transferring too many responsibilities to the institution of the state.

\subsection{The third beginning, or the problem of dualism in Adam Smith's thought}

The next stop on our journey to the idea of social economy is the emergence of economics as a new discipline of humanistic thought as well as a new form of management.

The moral philosopher Adam Smith opened one of his earlier books entitled The Theory of Moral Sentiments by stating:

How selfish soever man may be supposed, there are evidently some principles in his nature, which interest him in the fortune of others, and render their happiness necessary to him, though he derives nothing from it, except the pleasure of seeing it. Of this kind is pity or compassion, the emotion which we feel for the misery of others, when we either see it, or are made to conceive it in a very lively manner. That we often derive sorrow from the sorrow of others, is a matter of fact too obvious to require any instances to prove it. $(1989$, p. 5)

And on subsequent pages of the same book, the then father-to-be of economics wrote:

How amiable does he appear to be, whose sympathetic heart seems to re-echo all the sentiments of those with whom he converses, who grieves for their calamities, who resents their injuries, and who rejoices at their good fortune! [...] And for a contrary reason, how disagreeable does he appear to be, whose hard and obdurate heart feels for himself only, but is altogether insensible to the happiness or misery of others! $(1989$, p. 29)

And towards the end of the book, he noted:

Though our effectual good offices can very seldom be extended to any wider society than that of our own country; our good-will is circumscribed by no boundary, but may embrace the immensity of the universe. We cannot form the idea of any innocent and sensible being, whose happiness we should not desire, or to whose misery, when distinctly brought home to the imagination, we should not 
have some degree of aversion. The idea of a mischievous, though sensible, being, indeed, naturally provokes our hatred: but the ill-will which, in this case, we bear to it, is really the effect of our universal benevolence. It is the effect of the sympathy which we feel with the misery and resentment of those other innocent and sensible beings, whose happiness is disturbed by its malice. (1989, p. 350)

He went on:

The wise and virtuous man is at all times willing that his own private interest should be sacrificed to the public interest of his own particular order or society. $\mathrm{He}$ is at all times willing, too, that the interest of this order or society should be sacrificed to the greater interest of the state or sovereignty, of which it is only a subordinate part. He should, therefore, be equally willing that all those inferior interests should be sacrificed to the greater interest of the universe, to the interest of that great society of all sensible and intelligent beings, of which God himself is the immediate administrator and director. $(1989$, p. 351$)$

Seventeen years later, however, in his unquestionably most famous work entitled An Inquiry into the Nature and Causes of the Wealth of Nations, Smith put forward the view that was entirely dissimilar to his previous deliberations:

It is not from the benevolence of the butcher, the brewer, or the baker that we expect our dinner, but from their regard to their own interest. (1954, Vol. 1, p. 5)

In the light of his thoughts conveyed in The Theory of Moral Sentiments, even more surprising (in a certain interpretation) seems to be the sentence found on the next pages of the "bible of economists":

I have never known much good done by those who affected to trade for the public good. (Smith, 1954, Vol. 1, p. 45)

The analysis of what happened later with Adam Smith's philosophy clearly indicates that the attitude from The Wealth of Nations, which laid the foundation of economics, turned out to be of more importance to the socioeconomic thought, which was at the time in the phase of development, than the approach adopted in The Theory of Moral Sentiments. The founder of economics defeated the moral philosopher, and for centuries to come, the victorious stance determined the perception of a human being (as homo economicus) and the objective relation between persons.

\footnotetext{
${ }^{3}$ The problem with the interpretation of this sentence lies in the word "affected" - if understood literally as "pretended, faked", it is trivial; and if not literally, then Smith might have been concerned that economic activity undertaken in the name of good does not bring benefits.
} 


\subsection{The fourth beginning, or the pioneers of social economy}

The praise of poverty and the motto miser res sacra, which are typical of the Middle Ages, allowed a support system to be developed in which "mercy and salvation acted as an incentive, while alms ${ }^{4}$ and funding-means to provide the support" (Frączak, 2006, p. 7; cf. Leś, 2001).

A good example of such a support system was the fraternal fund of diggers founded by Seweryn Boner, who donated the famous golden horn of Wieliczkaa masterpiece of Renaissance goldsmith's art. The fund operated as a mutual insurance organization, providing handouts in the event of an accident or illness, and sometimes also pensions for the poorest. It functioned for over 400 years, until the times of socialism (cf. Bratkowski, 2000, p. 199).

The corporate system that was popular in the Middle Ages was grounded in a philosophy which resembles the ideas of social economy. Hospitals and religious orders were some of the social enterprises of those times. Medieval man lived mostly in collectives, in rural and urban communities such as guilds or fraternities. ${ }^{5}$

\section{As Maciuszko observes:}

probably the whole problem of welfare in the modern era could be summarized in defining the transformation of Christian charity into public charity (at least in terms of organizational and institutional forms). (1999, as cited in Frączak, 2006, p. 8)

Nowadays, the fight against exclusion is undeniably one of the positive outcomes of Christian charity changing into public good. Without a doubt, the process was also rooted in the modern idea of democracy and the Reformation, which assumed that well-performed work is a manifestation of fulfilled Christian responsibility towards society.

In this spirit, Germany introduced the "social market economy" policy in 1948, and thus created the Rhine variety of capitalism (cf. Albert, 1994), whereas France launched an experiment with the socialization of capitalism, called the "social economy" [Polish: ekonomia socjalna] as a sector of the economy, which is neither private nor public, but organized around cooperative ownership. Concepts related to the social economy can also be found in the social teachings of the Church (cf. the papal encyclicals Rerum Novarum (1891) and Laborem exercens (1981)).

\footnotetext{
${ }^{4}$ We shall omit in our deliberations the negative consequences of alms in the form of beggary, which led to the creation of so-called "beggar's quotas" (cf. Leś, 2001).

${ }^{5}$ In 1914, 3,745 cooperatives were in operation in the Polish lands, uniting 1,458,562 members. Their shares totaled 1 million "gold francs", while their saving accounts amounted to 1 billion "gold francs".
} 


\section{What is the social economy?}

\subsection{Growing pains}

When a new research area emerges, various names and definitions of it are proposed, numerous attempts are made to put its essence into words. It was no different in the case of social economy. However, thus far no clear definition of it has been offered. The concept is still in the phase of being developed, emerging from the depths of civic consciousness, which are not yet fully explored, as well as from the social needs that are becoming increasingly palpable. Social consciousness is formed when a community encounters an impenetrable barrier, when without a new perspective or a new solution, further social development appears hampered, and its stability is put at risk.

Those interested in social economy observe that since the development of this concept is still in its initial phase, some scholars may speak of its chaotic nature ${ }^{6}$ inconsistent image (cf. Szopa, 2007, p. 4) and banality. ${ }^{7}$

\subsection{Definitional ambiguity}

The problem that the field of social economy faces is the multitude of terms. In Poland, just as in other countries, there is an ongoing discussion over the most accurate name for the emerging phenomenon. While some apply the term ekonomia społeczna [social economy], others believe that gospodarka spoteczna [social economy] $^{8}$ or spoleczna gospodarka rynkowa [social market economy] are more suitable expressions [in Polish, the term ekonomia stands for both, "economy" and "economics"; gospodarka stands for "economy"-translator's note]. There are also those who would opt for ekonomia socjalna [social/welfare economy] or the concept of "sustainable development."

Unlike their colleagues from the social field, mainstream economists are usually unwilling to accept the term ekonomia społeczna [social economy] (regardless of how it might be defined) for fear that the concept may replace traditional eco-

\footnotetext{
${ }^{6}$ Izdebski upholds, however, that calling the social economy a chaotic concept is an exaggeration since "thus far, not even a chaotic concept of the social economy exists, but numerous - sometimes maybe chaotic - attempts to define what the social economy exactly is and can be" (2007, p. 49).

7 "Economy, as witnessed by the origins of both the concept itself and the scientific discipline named by it, is essentially a social science. So maybe 'social economy' is a pleonastic and banal expression? In fact, the concept of social economy can be accused of banality from 'both sides,' so to speak: to say that economy is essentially a social science or that economic activity is obviously a social process (with its social origins and implications) is equally unenlightening as to say that social activity (construed here as activity aimed at social change, even on a very small scale) has its economic aspects (in the sense that it, in general, requires gathering and spending of financial resources, employing people, etc.)" (cf. Wygnański \& Frączak, 2006, p. 4).

${ }^{8}$ From the linguistic point of view, given the foreign-language versions of the term, some people believe that the name gospodarka spoleczna should be used (cf. B. Szopa, 2007, p. 4). "The use of the term social economy [here: ekonomia społeczna - translator's note] is disputable. [...] It became widespread and probably in Poland we will keep using this unreflective translation" (Hausner, 2007, p. 9).
} 
nomics. And when they do use the term, many of them assert that "social economy is not a branch of economics (and thus a new scientific discipline), but a sector of the economy distinguished due to its specificity, in which economic activity is seen as closely related to social goals" (cf. Szopa, 2007, p. 4) or that "it is not so much about a new approach to the economy or its separate branch, but about a specific segment of economic activity inscribed in a triangle whose sides are marked out by a market economy, civil society and a democratic state" (Hausner, 2007, p. 9). ${ }^{9}$ The author of the latter statement suggests positioning it in the following manner: firstly, as an alternative to both pure market solutions and excessive statization of the economy (it encompasses forms of exchange that can offer a radical alternative to the already existing ones). Secondly, the social economy can be seen as a specific method of market participation (it is a response to market failures).

Generally speaking, the social economy is a type of venture in which a community is to provide services or produce goods, while ensuring that human capital is greater than the financial capital, maintaining (at least partial) independence from the public sector and the democratic way of functioning. ${ }^{10}$ Examples of entities that undertake economic activity and operate in the sphere of the social economy include cooperatives, provident funds, foundations, associations, insurance companies, self-help groups and social enterprises.

\subsection{Social economy and the preferential option for the poor}

Going back to the considerations from "the first beginning", it should be stressed that the notion of the social economy does not coincide exactly with the concept of the preferential option for the poor, though in a way it contains the concept in itself (even if just historically). The social economy is a much broader concept, in which the emphasis is placed not only on the phenomenon of poverty and the methods of its eradication, but first and foremost on the phenomenon of social exclusion and its elimination.

Thus, the liberal arguments used against the preferential option for the poor cannot be advanced in the critique of the social economy. It cannot be done since the idea of the social economy does not originate from the premise of the "bucolic harmony" of the world (which, after all, we are not experiencing), or from the premodern image of humanity as an agricultural community (which no longer exists), and surely it is not based on the naively understood idea of equality or distributive justice (i.e. ideals impossible to attain, mainly due to the lack of adequate

\footnotetext{
${ }^{9}$ At the same time, the author notes: "in order to be social, it cannot substitute or displace the market, and the same goes for the public economy."

${ }^{10}$ Among more specific and debatable issues related to the social economy are the following questions: Is this idea more of a social problem or rather an economic issue? Is it a subject of the new economy or a new element of the old economy? Is it a part of the third sector or does it simply make use of its inherent potential? Does it fall within the scope of the broadly defined social assistance or only serve such a function?
} 
production methods). It directly stems from the democratic idea of "equality of access" as well as human and civil rights, and it relates to the mechanisms of the free market. What is more, it is rooted in the belief that a large part of the excluded persons found themselves in this situation not so much due to a lack of talent or disabilities (in which case the nature would be at fault), and not because of too low motivation to work or addictive tendencies either (which would be mainly their own fault), but as a result of faulty market mechanisms and the weakness of the democratic system. The point is that the mechanisms created by humans "push" part of the population to the margins of society, irrespective of their will. The social economy is also grounded in the conviction that, in the long run, the "army of the excluded" will slow down the rate of economic growth and hence social development, while the feeling of resentment that builds up among the excluded people may threaten the socioeconomic stability over time. And so the best way to avoid these threats is to manage rationally the "potential of the excluded."

What does not apply to the social economy either is the claim made against the preferential option for the poor, to which Berger (1994, p. 8) draws attention: "if one affirms a preferential option for the poor, one must ask which 'modes of production' (to use Marx's handy term) are most conducive to the mitigation or the eradication of poverty," meaning that since no method of production was found effective in solving the problem, it seems impossible to adhere to this principle in any society. This allegation is unfounded in the case of the social economy as it is precisely the attempt to find the production methods that would allow the problem of social exclusion to be solved or its scope limited, without sticking to the preferential option that involves various forms of handouts.

\subsection{The social economy and the economy}

Being founded on values is what sets the social economy apart from other economic activities (free market economy). Supporters of the social economy agree that the values constituting the distinguishing features of social economy are solidarity and social cohesion, social responsibility and commitment, democracy and participation, and autonomy and independence (for more on the subject cf. Mazur $\&$ Pacut, 2006). In addition, activities undertaken in this field are based on local activity, and therefore they remain culturally differentiated as their undertaking results from the type and nature of exclusion. They reflect the specific needs of a particular socially excluded group (which are frequently different from the needs of the rest of society).

The mentioned values are not the only distinguishing features of the social economy. Other include specific rules according to which the activity in the area of the social economy takes place. These are: 
(1) the precedence of service to its members or the community over profit (social utility);

(2) autonomous management;

(3) a democratic decision-making process;

(4) the primacy of people and work over capital in the distribution of revenue;

(5) being locally rooted.

Then, what distinguishes a social enterprise from an enterprise of the market economy or of the public economy is first of all, the question of profit, the scale of economic activity, localness, employed people as well as the type of competitiveness, and secondly - the type of control (for more on the subject of a social enterprise: Hausner, Laurisz \& Mazur, 2006).

\subsection{The objectives of the social economy}

In the discussion on the social economy, one of the arguments for developing this form of management is the benefits it brings: first, it prevents exclusion thanks to employment support programs; second, it enhances social capital; third, it recreates the local public space; fourth, it encourages putting the idea of citizenship into practice; fifth, it facilitates the reformation of the public service sector; sixth, it fits perfectly with the idea of building participatory democracy; seventh, it is part of the employment growth; eighth, it strengthens the process of social integration.

In the context of the social economy, it is worth considering what the historically distant but also more direct causes for the concept to appear were. In a nutshell, it can be said that firstly, the social economy is an answer to the split between the concept of civil society as a political society (with its inalienable rights and political freedoms) and the society of independent and autonomous economic entities (equipped with economic rights and freedoms). Secondly, it emerged as a consequence of the regression of the welfare state and, thirdly, due to the fall of the idea of state interventionism.

To understand the full scale of the problem, one should refer to the numbers. At the beginning of the $21^{\text {st }}$ century, the social economy sector constitutes about $8 \%$ of European entities (enterprises and producer organizations), 10\% of GDP and $10 \%$ of total employment in the economy (for more on specific solutions, cf. Borzaga \& Santuari, 2005).

Some people refer to this type of economy as "democratic capitalism, which operates based on widely available property rights and broadly defined economic freedoms, and which makes use of all forms of social capital, and thus includes into economic circulation all types of group ownership: the cooperative, the communal and the employee stock ownership" (Hausner, 2007, p. 9). 


\subsection{Dilemmas and difficulties}

No matter how we conduct the discussion on the concept of the social economy and its dynamically growing sector, some dilemmas and difficulties present themselves - as is always the case with social matters - in the sphere of theoretical considerations as well as of a specific practice.

As for dilemmas, the following issues come to the fore:

(1) What should be the nature and scope of cooperation between activities in the area of the social economy and the traditionally understood economy?

(2) What should be the level of competitiveness of social economy entities?

(3) What should be the scope of dependency and support that social economy entities receive from the state?

(4) What should be the nature and scope of legal changes that foster the development of social economy entities? ${ }^{11}$

Regardless of the answers, today it is already clear that apart from the support for those in need (the excluded), society needs "enlightened, morally unwavering individuals," who are able to pave the way for a new organization and implement the centuries-old idea of brotherhood. Moreover, if the undertakings of the social economy are to involve more economy than social welfare, the entities operating in its sphere cannot be completely dependent on the state, though undoubtedly some kind of patronage is necessary in order to create favorable conditions for their activity.

\section{A full circle}

According to David Novak, the biblical solutions - which were mentioned in "first beginning"- take on the character of "the prime responsibility containing the following lower-level responsibilities: responsibility for the land, responsibility for others, responsibility for one's own future" (Novak, 1994, p. 48). Yet, it is the idea of the social economy, as well as its practice developed in European countries, that truly and fully implement the idea of responsibility. It is the perspective of the social economy that gives all of us the opportunity to take responsibility for others and, even more importantly, provides the excluded ones with real opportunities to shoulder responsibility for themselves and their fate.

We may say that the original thought on supporting the "needy" has gone full circle and has returned in a new form, to which we refer today as the social economy, grounded in the idea of responsibility that was "lightened up" in the $20^{\text {th }}$ century by the adherents of existentialism and the philosophy of dialogue. Now, the whole economy and all people face the challenge of implementing this idea properly in the sphere of the social economy.

\footnotetext{
${ }^{11}$ For more on the dilemmas associated with a social enterprise, cf. Filek, 2008.
} 


\section{References}

Albert, M. (1994). Kapitalizm kontra kapitalizm. Kraków: Signum.

Berger, P. L. (1994). Wstęp. In P. L. Berger (Ed.), Etyka kapitalizmu. Kraków: Signum.

Borzaga, C., \& Santuari, A. (2005). Przedsiębiorstwa społeczne we Włoszech. Warszawa: Ministerstwo Pracy i Polityki Społecznej.

Bratkowski, S. (2000). Podróż do nowej przeszłości. Warszawa: VEDA.

Filek, J. (2008). Garść rozważań wokół problematyki przedsiębiorstwa społecznego. Ekonomia Spoteczna, 3, 12-18.

Filek, J. (2009). Ekonomia społeczna jako nowe wyzwanie. Annales. Ethics in Economic Life, 12(1), 179-188.

Frączak, P. (2006). Szkic do historii ekonomii społecznej w Polsce. Ekonomia Społeczna Teksty. wiadomosci.ngo.pl/files/ekonomiaspoleczna.pl/public /Raport_Otwarcia/Fraczak_Historia.pdf

Hausner, J. (2007). Ekonomia społeczna jako sektor gospodarki. Ekonomia Społeczna, 1, 9-14.

Hausner, J., Laurisz, N., \& Mazur, S. (2006). Przedsiębiorstwo społeczne - konceptualizacja. In J. Hausner (Ed.), Zarzadzanie podmiotami ekonomii spotecznej (Vol. 2, pp. 9-20). Kraków: Małopolska Szkoła Administracji Publicznej Uniwersytetu Ekonomicznego w Krakowie.

Izdebski, H. (2007). Czym jest ekonomia społeczna? Ekonomia Społeczna, 1, 49-50.

John Paul II. (1981). Laborem exercens. http://w2.vatican.va/content/john-paulii/en/encyclicals/documents/hf_jp-ii_enc_14091981_laborem-exercens.html

Jonas, H. (1996). Zasada odpowiedzialności. Etyka dla cywilizacji technologicznej (M. Klimowicz, Trans.). Kraków: Wydawnictwo Platan.

Leo XIII. (1891). Rerum novarum. http://w2.vatican.va/content/leo-xiii/en/encyclicals/documents/hf_l-xiii_enc_15051891_rerum-novarum.html

Leś, E. (2001). Zarys dobroczynności i filantropii w Polsce. Warszawa: Prószyński i S-ka.

Maciuszko, J. T. (1999). Miłosierdzie $w$ rozumieniu historycznego protestantyzmu. In U. Augustyniak, \& A. Karpiński (Eds.), Charitas. Mitosierdzie i opieka społecz$n a w$ ideologii, normach postępowania $i$ praktyce społeczności wyznaniowych w Rzeczypospolitej XVI-XVIII wieku. Warszawa: Semper.

Mazur, S., \& Pacut, A. (2006). Ekonomia społeczna i jej wartości konstytutywne. Ekonomia Spoleczna Teksty. http://www.ekonomiaspoleczna.pl/files/eko- nomiaspoleczna.pl/public/Biblioteka/2006.28.pdf

Novak, D. (1994). Ekonomia i sprawiedliwość: przykład żydowski. In P. L. Berger (Ed.), Etyka kapitalizmu. Kraków: Signum.

Skąpska, G. (2007). Społeczeństwo obywatelskie: kontekst i płaszczyzny funkcjonowania. Ekonomia Społeczna, 1, 22-32.

Smith, A. (1954). Badania nad natura i przyczynami bogactwa narodów (Vol. 1). Warszawa: Państwowe Wydawnictwo Naukowe.

Smith, A. (1989). Teoria uczuć moralnych (S. Jedynak, Trans.). Warszawa: Państwowe Wydawnictwo Naukowe. 
Szopa, B. (2007). Od Redakcji. Ekonomia Społeczna, 1, 4-7.

Wygnański, J., \& Frączak, P. (2006). Ekonomia społeczna w Polsce - definicje, zastosowania, oczekiwania, wątpliwości. Ekonomia Społeczna Teksty. http://www.ekonomiaspoleczna.pl/files/ekonomiaspoleczna.pl/public/Biblioteka/20 06.6.pdf 